\title{
Mapping the Fuggerzeitungen: The Geographical Issues of an Information Network
}

\author{
Nikolaus Schobesberger
}

\section{Introduction}

The sixteenth century was characterised by the unprecedentedly rapid acceleration and standardisation of the information and communication system, to an extent that would remain unparalleled until the nineteenth century and the invention of the electric telegraph. ${ }^{1}$ The Imperial postal system and the development of written media, available to the public at large for the first time, both have their origin in the century or so between 1490 and 1605 and were an important factor in the development of a bourgeois information society during the following centuries. ${ }^{2}$ Elites became more and more interested in events taking place all over Europe. Politically as well as economically, it is possible to discern an early form of globalisation. ${ }^{3}$ Based on the new confessional divides of the Reformation, new alliances were formed and boundaries drawn across the continent. Reporting of war and conflict, such as the Dutch War of Independence, suddenly acquired new interest for a pan-European audience because of its frequently confessional character. At the same time this early capitalist society, which was beginning to view markets and economic processes in global terms, developed a need for information that could only be

1 Michael North, ed., Kommunikationsrevolutionen-Die neuen Medien des 16. und 19. Jahrhunderts (Köln, Weimar, Wien: Böhlau, 2001), pp. ix-x; Wolfgang Behringer, Im Zeichen des Merkur-Reichspost und Kommunikationsrevolution in der frühen Neuzeit (Göttingen: Vandenhoeck \& Ruprecht, 2003), pp. 14-15.

2 In 1490 Kaiser Maximilian I instructed the Taxis family to establish a post route between Innsbruck and Brussels; see Behringer, Im Zeichen des Merkur, p. 59. In 1605 the first printed, periodic newspaper was issued by Johann Carolus in Strasbourg. See Johannes Weber, 'Straßburg 1605-Die Geburt der Zeitung',Jahrbuch für Kommunikationsgeschichte, 7 (2005), pp. $3^{-27}$.

3 Thomas Schröder, Die ersten Zeitungen - Textgestaltung und Nachrichtenauswahl (Tübingen: Narr, 1995), pp. 1-7. Johannes Arndt, Esther-Beate Körber, eds., Das Mediensystem im Alten Reich der Frühen Neuzeit (160o-1750) (Göttingen: Vandenhoeck \& Ruprecht, 2010), pp. 9-10.

(C) NIKOLAUS SCHOBESBERGER, 2016 | DOI 10.1163/9789004277199_010 
satisfied by new media. ${ }^{4}$ One such development is the emergence of handwritten newsletters ('Zeitungen'), including the Viennese Fuggerzeitungen. ${ }^{5}$

Because historical research had long considered the invention of printing as the driving force behind the development of the modern periodical printed newspapers, other media, particularly handwritten newsletters, largely went unregarded. ${ }^{6}$ In Italy handwritten newsletters, called avvisi, began to appear from the fifteenth century onwards, as a development of the diplomatic dispatch system. ${ }^{7}$ Initially they took the form of attachments to letters, spreading news and satisfying the growing demand for information. During the sixteenth century, those newsletters developed into an independent form of news media which, in contrast to the printed broadsheets of the time, arrived with regular or semi-regular periodicity and dealt with serious topics. Recent findings show that the modern press is a further development of handwritten newsletters, arising from the invention of cheaper and quicker printing processes. ${ }^{8}$ The Viennese Fuggerzeitungen are among the best-known collections of these handwritten newsletters.

\section{The Fuggerzeitungen}

The term Fuggerzeitung appears frequently in studies on the history of media and communication. Originally it was used for all kinds of letters containing news and handwritten newsletters collected and shared amongst the Fugger

4 Oswald Bauer, Zeitungen vor der Zeitung-Die Fuggerzeitungen (1568-1605) und das frühmoderne Nachrichtensystem (Berlin: Akademie Verlag, 2011), p. $3^{2 .}$

5 For more information on the development of handwritten newspapers, see Bauer, Zeitungen vor der Zeitung, pp. 31-42.

6 Jürgen Wilke, Grundzüge der Medien- und Kommunikationsgeschichte (Cologne \& Vienna: Böhlau, 2008), pp. 13-14.

7 See esp. Cornel Zwierlein, 'Fuggerzeitungen als Ergebnis von italienisch-deutschem Kulturtransfer 1552-1570', Quellen und Forschungen aus italienischen Archiven und Bibliotheken, 90 (2010), pp. 176-7; see also Bauer, Zeitungen vor der Zeitung, p. 33.

8 Bauer, Zeitungen vor der Zeitung, pp. 40-2; Weber, 'Straßburg 1605', pp. 3-26; Johannes Weber: “Unterthenige Supplication Johann Caroli/Buchtruckers"-Der Beginn gedruckter politischer Wochenzeitungen im Jahr 1605', Archiv für Geschichte des Buchwesens, 38 (1992), pp. 257-65. Schröder, Die Ersten Zeitungen, pp. 10-13; Holger Böning: "Gewiss ist es/dass alle gedruckten Zeitungen erst geschrieben seyn müssen"-Handgeschriebene und gedruckte Zeitung im Spannungsfeld von Abhängigkeit, Koexistenz und Konkurrenz', Daphnis, 37 (2008), pp. 203-42. 
family between the middle of the sixteenth and beginning of the seventeenth century. $^{9}$ In a narrower sense, the term Fuggerzeitungen means the corpus of handwritten newsletters assembled by the brothers Octavian Secundus (1549-160o) and Philipp Eduard Fugger (1546-1618). The collection has formed part of the Imperial Court library since 1656 and is now to be found in the collection of manuscripts and early prints of the Austrian National Library (Österreichische Nationalbibliothek, hereafter ÖNB). It contains a total of 27 folio volumes (Cod. 8949 to 8975 ), amounting to approximately 16, ooo newsletters from 1568 to $1605 .{ }^{10}$ The collected newsletters are reports, usually with a dateline for a title, and varying in length from a few lines to six pages in total. Each newsletter consists of one or more news items, each of which is typically accorded its own separate paragraph. Around $82 \%$ of the newsletters are written in German, with $17 \%$ in Italian; French, Spanish and Latin each represent less than $1 \%$ of the total. ${ }^{11}$

Previous research has strongly insisted on seeing the Fugger newsletters in an economic context, and consequently tended to assume that the Fuggerzeitungen were strictly an internal information service for the Fugger family business, used mainly to inform and support financial decisions. ${ }^{12}$ More recent work

For a definition of the Fuggerzeitungen and the history of research see Katrin Keller, 'Die Fuggerzeitungen-Ein Literaturbericht', Jahrbuch für Kommunikationsgeschichte, 14 (2012), pp. 186-204; Cornel Zwierlein, Discorso und Lex Die-Die Entstehung neuer Denkrahmen im 16. Jahrhundert und die Wahrnehmung der französischen Religionskriege in Italien und Deutschland (Göttingen: Vandenhoeck \& Ruprecht, 2006), p. 577; Kaspar Kempter, Die wirtschaftliche Berichterstattung in den sogenannten Fuggerzeitungen (Munich: Zeitungswissenschaftliche Vereinigung, 1936), pp. 6-7.

10 Bauer, Zeitungen vor der Zeitung, pp. 59-6o.

11 For the quantities of the Fuggerzeitungen see also Anita Hipfinger and Josef Löffler, Fuggerzeitungen-Digitales Bestandsverzeichnis, <www.univie.ac.at/Geschichtsforschung/ ressourcen/die-fuggerzeitungen> [8/04/15]; a quantitative analysis of the Fuggerzeitungen is also available in Anita Hipfinger and Josef Löffler, 'Die Wiener Fugger-Zeitungen—Eine Bestandsaufnahme', Mitteilungen des Instituts für Österreichische Geschichtsforschung, 117 (2009), pp. 379-98.

12 For the history of research on the Fuggerzeitungen see Keller, 'Fuggerzeitungen'; early researches on the Fuggerzeitungen; Johannes Kleinpaul, Die Fuggerzeitungen 1568-1605 (Leipzig, 1921); Victor Klarwill, Fugger-Zeitungen-Ungedruckte Briefe an das Haus Fugger aus den Jahren 1568-1605 (Vienna, Leipzig, Munich:Nikola Verlag, 1923); Kempter, wirtschaftliche Berichterstattung; Mathilde Fitzler, Die Entstehung der sogenannten Fuggerzeitungen in der Wiener Nationalbibliothek (Baden bei Wien: Rohrer Verlag, 1937); Theodor Gustav Werner, 'Regesten und Textevon Fuggerzeitungen derÖsterreichischen Nationalbibliothek in Wien', Scripta Mercaturae, 1 (1967), pp. 57-68; Theodor Gustav Werner, 'Das kaufmännische Nachrichtenwesen im späten Mittelalter und in der frühen Neuzeit und sein 
shows this hypothesis to be untenable. ${ }^{13}$ The proportion of economic reports in the Wiener Fuggerzeitungen is by no means large enough to constitute an adequate economic information service, making it impossible to maintain the notion that the family's economic decision-making could have been based solely or even principally on the Fuggerzeitungen. The Fuggerzeitungen cover a multitude of topics. One focal point is their political and military reporting, but besides these topics they range across such diverse events as social occasions, celebrations, court ceremonial, religious and confessional matters, and criminal cases. ${ }^{14}$

Another basic assumption common to much early work on the Fuggerzeitungen is that those newsletters were a private information medium intended only for the use of the Fugger family. This assumption must also be revised in the light of recent research on the origin and development of handwritten newsletters. ${ }^{15}$

It is certain that the Fugger trading house was to some extent involved in the distribution of the newsletters, but their role in this should not be overestimated. The Fuggerzeitungen are a detail of the sixteenth century media landscape, a detail that happens to have been preserved by Octavian Secundus Fugger's passion as a collector. Contrary to what has previously been supposed, it appears that not all of the writers of these newsletters were employees of the Fugger family business. In fact most of them were professional novellisti, or even private individuals, who came from the Imperial Court or marched with European armies and reported on the sixteenth century campaigns for newsletters like those of the Fugger family.

Supported by the Austrian Fund for Science and Research (österreichischen Wissenschaftsfond, or FWF), the project 'The Fuggerzeitungen: An early modern

Einfluss auf die Entstehung der handschriftlichen Zeitung', Scripta Mercaturae 2 (1975), pp. $3^{-52}$.

13 Zwierlein, Discorso und Lex Die; Bauer, Zeitungen vor der Zeitung, pp. 18-26.

14 For a statistical evaluation of the topics in the Fuggerzeitungen see Bauer, Zeitungen vor der Zeitung, pp. 189-201, at 197.

15 Zdeněk Šimeček, 'Geschriebene Zeitungen in den böhmischen Ländern um 1600 und ihr Entstehungs- und Rezeptionszusammenhang mit den gedruckten Zeitungen', in Presse und Geschichte II-Neue Beiträge zur historischen Kommunikationsforschung, ed. Elger Blühm, Hartwig Gebhardt (Munich: K.G. Saur, 1987), pp. 71-82; Zwierlein, 'Fugerzeitungen als Ergebnis', pp. 169-224; Zsuzsa Barbarics, 'Tinte und Politik in der Frühen NeuzeitHandschriftliche Zeitungen als überregionale Nachrichtenquellen für die Machthaber', PhD thesis (University of Graz, 2006); Böning, 'Gewiss ist es'; Zwierlein, Discorso und Lex Die; Bauer, 'Zeitungen vor der Zeitung', p. 33. 
informative medium and its indexing' ('Die Fuggerzeitungen. Ein frühneuzeitliches Information medium und seine Erschließung') was started in March 2011, overseen by Dr Katrin Keller. ${ }^{16}$ During this, we have been able to create a database containing all the writings from the Fuggerzeitungen, including the place and date of dispatch, the signature, and the people and locations mentioned in each article. This index of over 16,00o handwritten newsletters, letters, and other attachments will be added to the HANNA-catalogue of the National Library. Additionally, digital reproductions of the Fuggerzeitungen will be provided by the öNB.

The aggregation of all the Zeitungen into a single database for the first time allows more detailed statistical evaluation and geographical analysis of an early modern news medium, which will provide an overview of spatial structures, the European communications network in the early modern period, and their geographically differentiated development

\section{Essentials of a Geographic Analysis of the Fuggerzeitungen}

Reflections upon the spatial structures of the Fuggerzeitungen can already be found in some of the earliest research on this material. Johannes Kleinpaul and Victor Klarwill discovered and described the spatial structure of the Fuggerzeitungen in their breakdown of the archive by place of dispatch. ${ }^{17}$ Thus the most important cities-Antwerp, Cologne, Venice and Rome - were listed, and the Fuggerzeitungen perceived and characterised as encompassing the whole of Europe.

The first complete statistical evaluation of the places in the Fuggerzeitungen was not undertaken until 2009, when Anita Hipfinger and Joseph Löffler completed an inventory of all Fuggerzeitungen and when, following them, Oswald Bauer gave a more detailed overview of the textual records from the more important places and their catchment areas, as well as the most important lines of communication. ${ }^{18}$

A geographical survey of the Fuggerzeitungen immediately hints at the structure of the corpus. It can be asserted in general that each newsletter has

16 Website of the project: <www.univie.ac.at/fuggerzeitungen/en/> [8/04/15].

17 Kleinpaul, Die Fuggerzeitungen, 15-16; Klarwill, Fugger-Zeitungen; for Klarwill the most important information centres are Antwerp, Middelburg, Cologne, Lisbon and Madrid (p. 18).

18 Hipfinger and Löffler, Digitales Bestandsverzeichnis (2007), p. 5; Bauer, Zeitungen vor der Zeitung, pp. 63-70. 
a place of dispatch, from which the writer reports about a certain region, or catchment area. The newsletters were then sent to Augsburg by post or courier and collected there. This transport structure suggests three categories of spatial questions arising from the Fuggerzeitungen.

\section{$1 \quad$ By Place of Dispatch}

Usually each newsletter has a dateline for a title. At the place of dispatch, the newsletter was compiled and sent. Looking at the frequency with which the various points of dispatch occur within the corpus, we see the relative importance of specific cities within the European news network in general and the Fuggers' information network in particular. Based on changes in the frequency of the news received from various places across the whole period covered by the corpus, we can distinguish the most important places at which news was gathered and transmitted. In addition, these changes can be used to track changes in the structure of the news itself, influenced by events.

\section{$2 \quad$ By Catchment Area}

'Catchment area' is used here to describe the area covered by news reports from a given point of dispatch. Investigating the catchment areas of the most important news-gathering centres in the Fugger network demonstrates the regional importance of the various centres of information. Only in a very few cases do the reports of the Fuggerzeitungen cover one place only. More commonly they embrace a wider area, more or less clearly defined, and news from this area was collected and written down at the same place from which the newsletter or was eventually sent. Catchment areas thus show the spatial structure of the early modern news network.

\section{The Early Modern Information Network}

By reference to the routes news travelled and the time it took to do so we can establish a spatial and temporal information network across Europe. The routes the newsletters took can be defined based on the Fuggerzeitungen insofar as sometimes several newsletters from different places along one route are written on the same sheet of paper in consecutive order of the places passed. Using the sequence of places the newsletters passed through en route and the time taken for each stage, we can reconstruct this network fairly accurately. ${ }^{19}$ Additionally, the structure of each newsletter shows that there were other centres of information besides the places of dispatch. These centres seldom appear

19 For the analysis of the duration of the Fuggerzeitungen see Bauer, Zeitungen vor der Zeitung, pp. 178-9. 
as places of dispatch, but were collection points for news that was then passed on to the places of dispatch recorded in the newsletter's dateline. For example, avvisi from Milan were very often included in newsletters from Venice. Similarly, news from Brussels might be included in Antwerp newsletters. It is thus apparent that the Fugger network made extensive use of the post routes already established in the mid-sixteenth century.

The content and structure of the Fuggerzeitungen are also in some respects geographically. Due to different traditions in the sophistication of the language used by the newswriters, in the levels of professionalism displayed in the writing, and in complexity of themes treated there are, for example, notable differences between Italian newsletters and those from north-western Europe.

Generally speaking, among the German-language newsletters in the collection those originating from cities on the main postal routes acquire a higher level of professional polish sooner than those from places further off the beaten track.

\section{Places of Issue}

As shown in the statistical evaluations of the Fuggerzeitungen by Hipfinger/ Löffler and Oswald Bauer, and mapped in Figure 9.1, the most frequent places of issue are Antwerp, Cologne, Rome and Venice with around 2,100 to 2,300 newsletters each, which amounts to approximately $13-16 \%$ of the total. ${ }^{20}$ Vienna, Prague and Lyon follow with around 6\% apiece; Constantinople trails with 304 (1.8\%). Frankfurt, Gran/Esztergom, Paris, Kaschau/Košice, Strasbourg and Middelburg each account for a little over $1 \%$. There are more than 450 distinct places of dispatch from all over Europe, Asia (for example Goa/India or Japan) and America (for example Santo Domingo, Mexico and Lima). About half of all places of dispatch occur only once in the index.

The places that appear frequently are either international centres of commerce, such as Venice and Antwerp, Cologne and Lyon, or places of political importance, like Rome (the home of the papacy), or Vienna and Prague (Imperial centres of the Habsburg monarchy).

A closer look shows that the transmission of the newsletters was by no means continuous. While the four principal centres forwarded an average of 1-2 newsletters each week, a closer look shows discontinuities in the flow of information. ${ }^{21}$

\footnotetext{
$20 \quad$ Hipfinger and Löffler, Digitales Bestandsverzeichnis (2007), p. 5; also Bauer, Zeitungen vor der Zeitung, p. 63 .

21 For the development of the main information centres of the Fuggerzeitungen see Bauer, Zeitungen vor der Zeitung, pp. 63-9.
} 


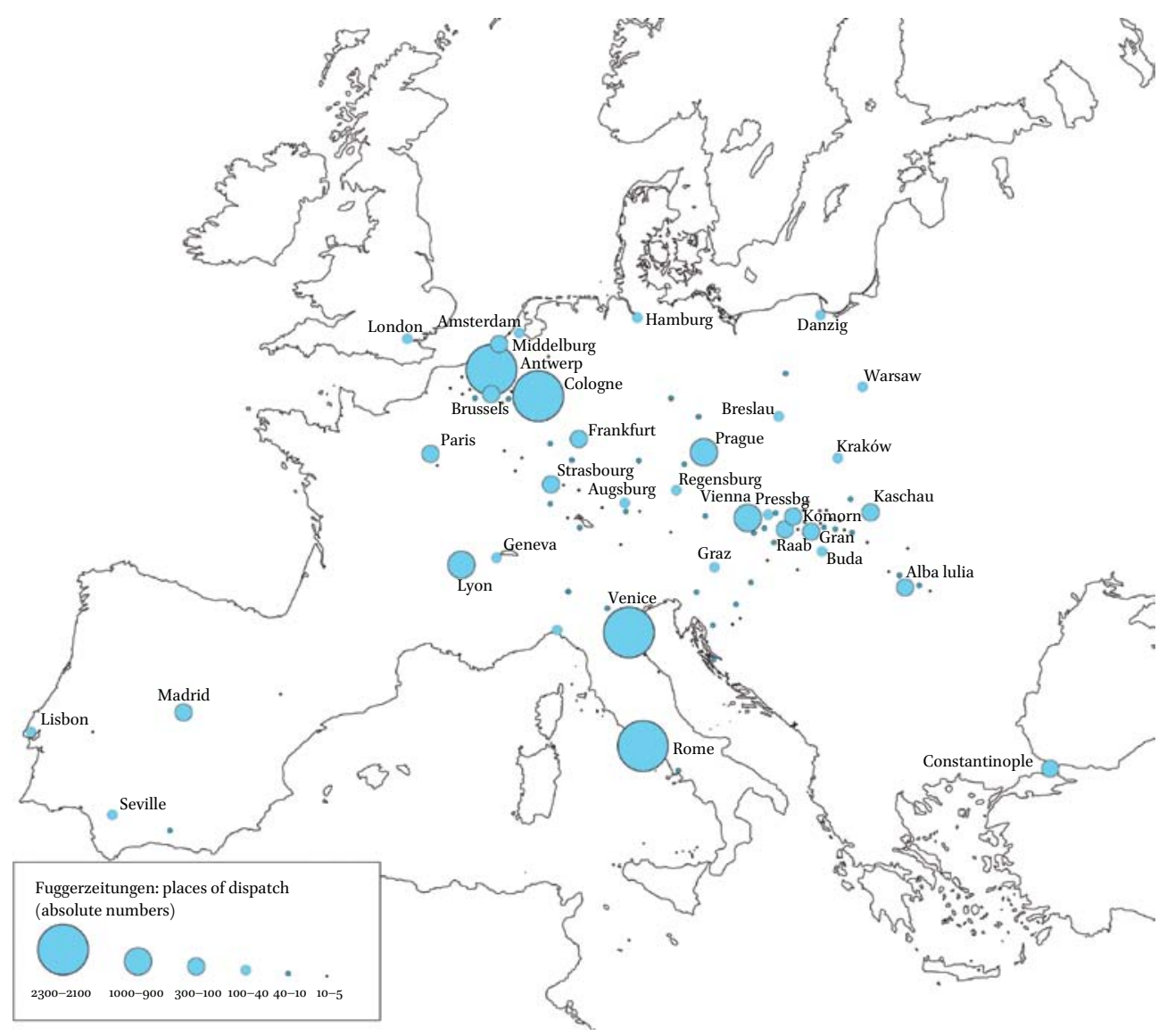

FIGURE 9.1 Distribution map of places of dispatch (1568-1605)

The first two volumes of the Wiener Fuggerzeitungen are not representative due to the manner of their compilation. In contrast to all other volumes, volume 8949 (1569-72) does not consist of original newsletters; all the texts in it were retrospectively compiled and copied. Volume 8959 only contains only newsletters written in Italian. Only from 1578 onwards we find a certain standardisation in the sequence of the Fuggerzeitungen.

That year, nearly one third of the newsletters came from Antwerp, followed by Rome and Venice with about $13-14 \%$ each (see Figure 9.2). The large number of newsletters from Antwerp is a consequence of the political situation of the Spanish Netherlands, as the Dutch War of Independence escalated. In general reports of the Eighty Years War were given particular prominence in the Fuggerzeitungen. 


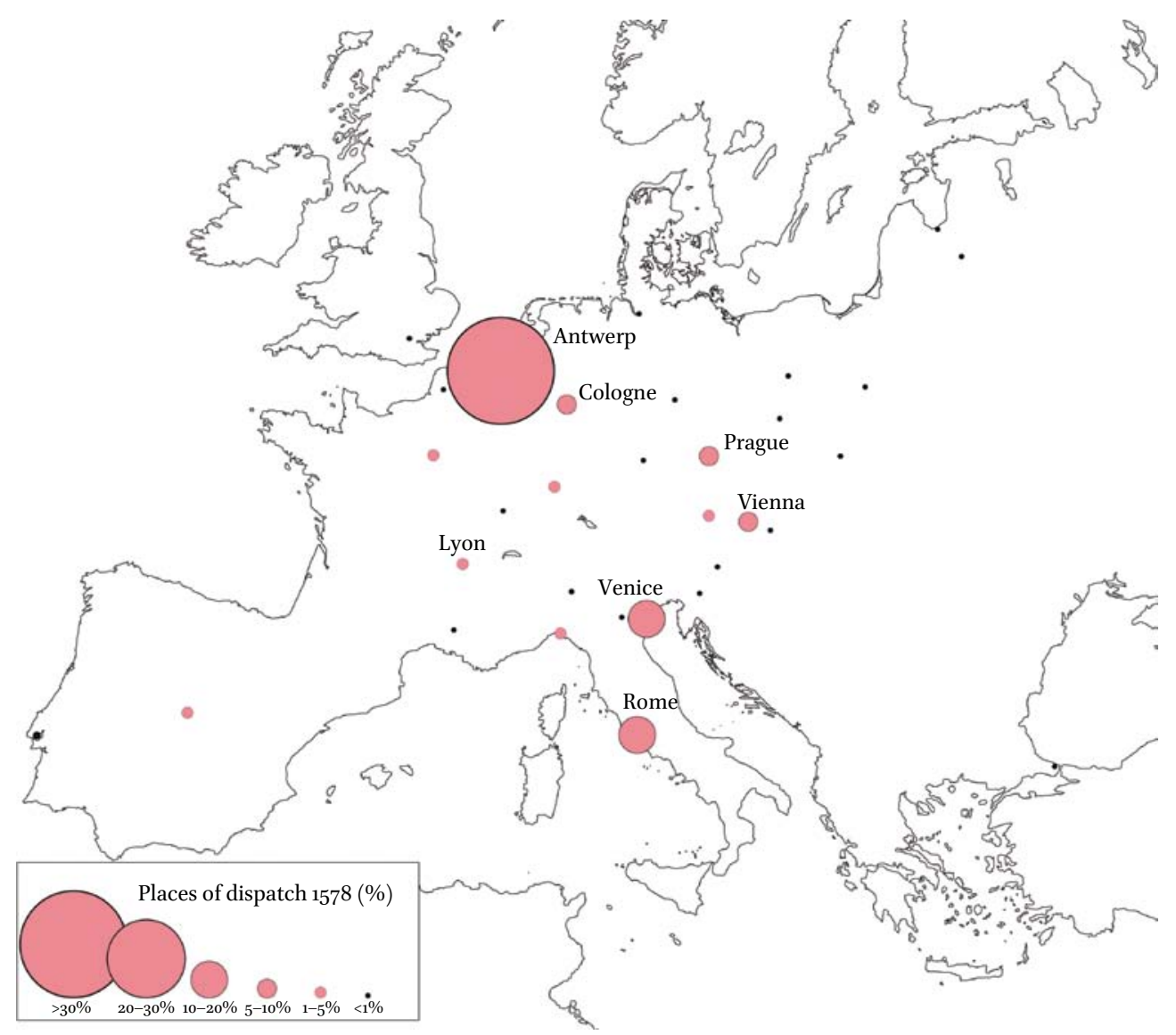

FIGURE 9.2 Distribution map of places of dispatch for Fuggerzeitungen (1578) Cod. 8951

In this volume the newsletters from Rome and Venice are written entirely in Italian. Compared to other volumes, Cologne does not occur very frequently as a place of dispatch. There is also a continuous sequence from France (via Paris and Lyon) and from the Habsburg territories (via Prague and Vienna). At the same time there are reports from Spain and Portugal, mainly because of Portugal's war against the Sultan of Morocco, which started in 1578 and took a decisive turn with the defeat of the Portuguese at Alcácer-Quibir and the death of King Sebastian.

Around 1588 Cologne is on a par with Antwerp as a news centre in Western Europe. The Cologne War (1583-8) tremendously increased the output of newsletters from the metropolis by the Rhine. ${ }^{22}$ Cologne's output had already begun to surpass Antwerp's by 1582. In 1588 the reporting from the Netherlands

22 Concerning the Cologne war in the Fuggerzeitungen see also Oswald Bauer, 'Reichspolitik in den Fuggerzeitungen (1568-1605) - Der Kölner Krieg (1583-1589) als Medienereignis mit reichspolitischer Relevanz', in Die Fugger und das Reich-Eine neue Forschungsperspektive 
and the Lower Rhine dominates, mainly because of the Spanish Armada. Between May and August 1588 reports on Spanish activity left Antwerp up to three times a week. ${ }^{23}$ Figure 9.3 shows yet another trend in the Fuggerzeitungen at the end of the 1580 s, namely the decline in the proportion of Italian newsletters. Rome and Venice make up only $5 \%$ of all reports. Between 1587 and June 1588 there is no news from Venice or Rome at all. Previously these reports were written in Italian, added separately at the beginning or end of each volume, as sealed and addressed sheets. By the middle of the year 1588 the reports from Venice and Rome resume, but are given in German from that point on.

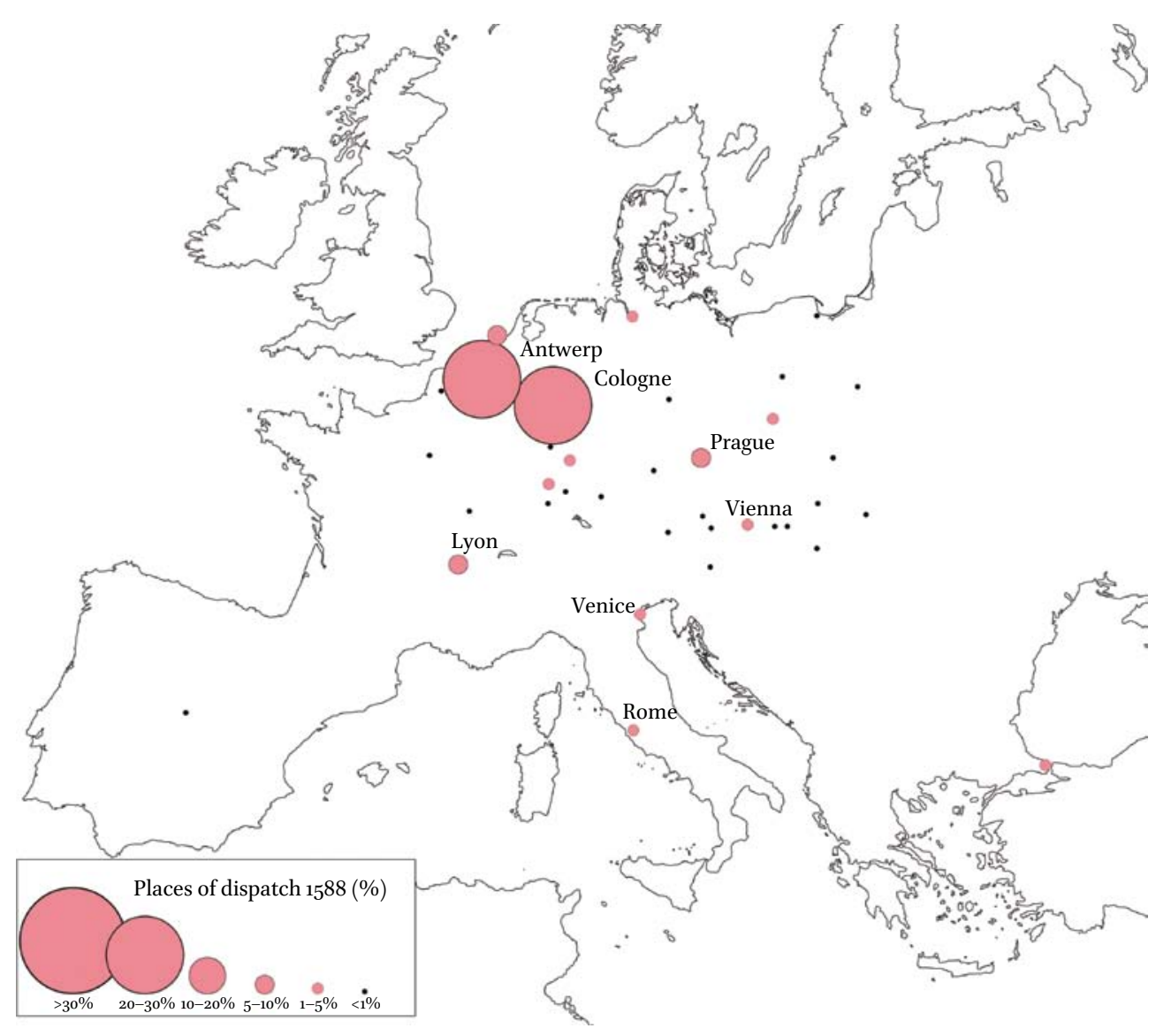

FIGURE 9.3 Distribution map of places of dispatch for Fuggerzeitungen (1588) Cod.8961

zum 5oojährigen Jubiläum der ersten Fuggerherrschaft Kirchberg-Weißenhorn, ed. Johannes Burkhardt (Augsburg: Wissner-verlag, 2008), pp. 269-88.

23 Concerning the reports on the Spanish Armada in the Fuggerzeitungen see also Bauer, Zeitungen vor der Zeitung, pp. 301-9. 
There is also continuous reporting from Constantinople between 1582 and 1592, with an average of one newsletter coming from Constantinople to Augsburg every two weeks. The reporting from the Ottoman Empire ends 1592 with the beginning of the Turkish War.

By the end of the 1590s the composition of the Fuggerzeitungen volumes looks very different, as shown in Figure 9.4. There is a diversification of the places of dispatch. The 'big four' (Antwerp, Cologne, Rome and Venice) remain, even though they make up only 10-13\% each, while by this time Vienna, Prague, Lyon and Gran each account for 5-8\%. Gran's greater significance can be attributed to the Turkish War (1592/3-1606). Reporting from the border towns of Croatia and Hungary increases notably after the beginning of this conflict. If the newsletters from the fortified towns (Gran/Esztergom, Kaschau/Košice, Komorn/Komárno, Pressburg/Bratislava, Neuhäusl/Nové Zámky, Raab/Győr und Tokaj) were added to those from Hungary they would equal those from Rome and Venice (12\%).

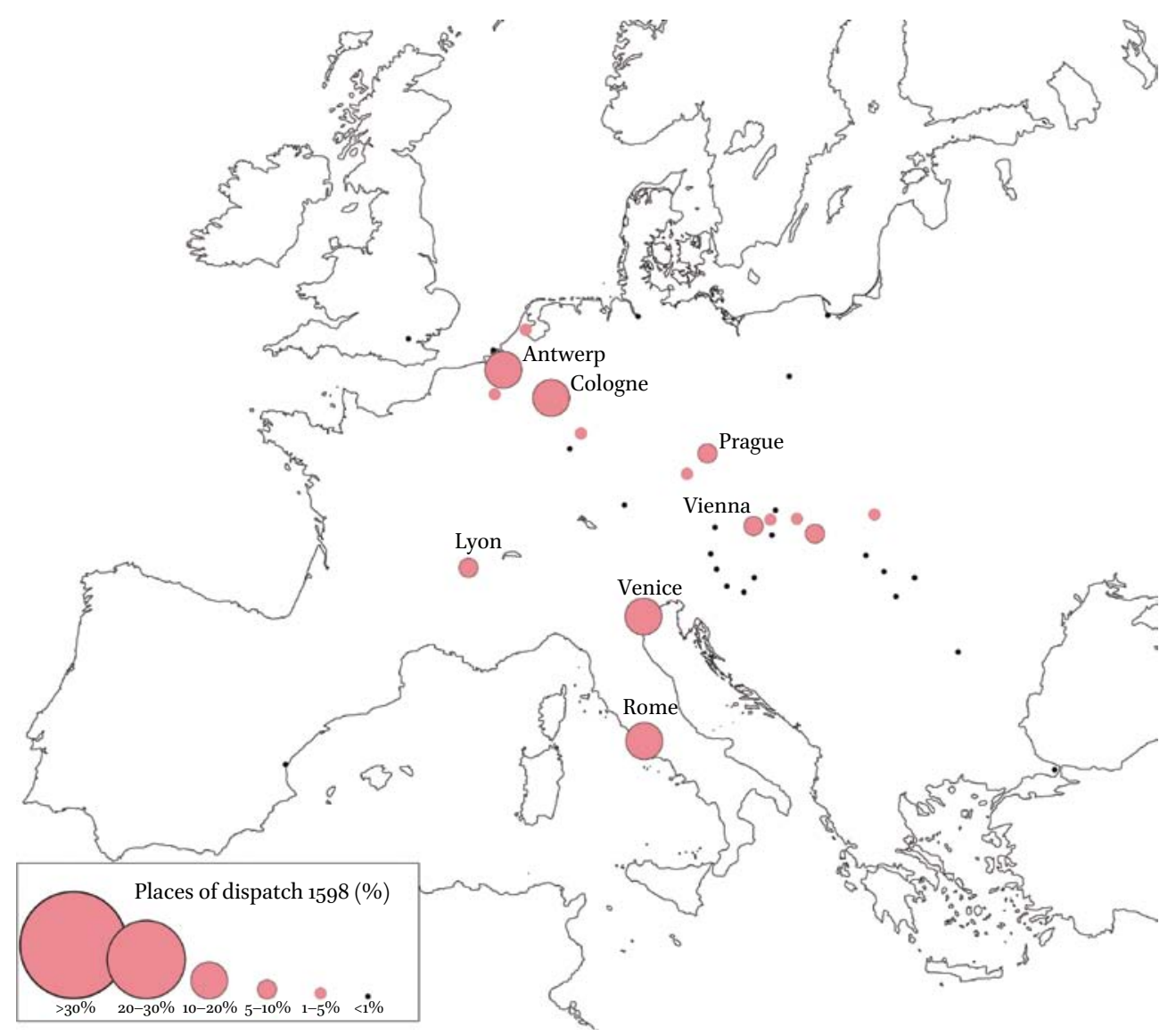

FIGURE 9.4 Distribution map of places of dispatch for Fuggerzeitungen (1598) Cod.8971 
The maps show two main trends in the geographical structures of news transmission: first, the reporting was closely related to political and military events. This is evident in the cases of the abovementioned conflicts (the Dutch Revolt, the Spanish Armada or the Turkish War, occurring at opposite ends of Europe). In contrast to the Dutch and Spanish conflicts, the Turkish War causes an upsurge of reports directly from the war zone, not only an increase of reports from the usual centres of information, for instance Vienna or Prague. Second, there is a significant diversification in the newsletters' places of dispatch. By the end of the 1570s there were only a few important places for the dispatch of newsletters, accounting for up to $30 \%$ of all Fuggerzeitungen collected during a year: Antwerp in 1578, for instance. By the end of the 1590 os there was a multitude of places from which they might originate.

Additionally there are certain places of dispatch — Lyon, Vienna or Prague, for instance - which make up a remarkably consistent proportion of the Fugger newsletters from year to year. This shows that apart from the interest in news from the four principal centres there was a continuous interest in what was going on in France and in the Habsburg monarchy, even though the statistics show some discontinuity in the tradition. ${ }^{24}$ Despite this, Lyon, Vienna and Prague remained cities of interest over several decades, whilst other politically important places (Paris, London, Madrid) were only covered by reports collected in other cities.

\section{Environs}

As already indicated, only a small percentage of reports in the Fuggerzeitungen deal with events specific to the places of dispatch. A large percentage of the news comes from the regions served by those centres. The place of dispatch is a central point in those regions, collecting information from all quarters.

We can visualise the catchment areas by researching and indexing the places mentioned in the newsletters. In most cases this gives us a core area and a surrounding region covered by the reports. One problem when mapping catchment areas is that merely mentioning ethnic groups or countries does not necessarily mean that a given newsletter actually reports on them. Thus it was decided to list all ethnic groups or nationalities under the name of their country-for example Spaniard is listed under Spain-including all subgroups.

The problem is illustrated in Figure 9.5, using the example of the Ottomans in newsletters from Vienna. In the 916 newsletters originating from Vienna we find the word 'Ottomans' 516 times ('Turks/Türken' in the original text). This is 
by far the highest number of any nationality mentioned, and it is mainly used for the Ottoman troops, usually located in Hungary or Croatia. Very occasionally the term refers to the Ottoman Empire itself, which also appears under this name. The map below may serve as a sample of a visualisation of the catchment area for places of dispatch. Newsletters have been excluded from the sample if they contain the words 'Ottomans' (in the case of the Viennese newsletters) or 'Spain' (in newsletters from Lyon), as the inclusion of these terms would have strongly skewed the data.

In Figure 9.5 I have tried to present the catchment areas of Vienna and Lyon. The circles indicate how often a place was mentioned in the Viennese and Lyonnais Fuggerzeitungen. It shows very clearly that newsletters from Lyon are dominated by news from France, especially from Paris and the Royal Court. Paris is mentioned in 600 out of the goo newsletters from Lyon; Paris's surroundings are also much mentioned, extending as far as the Dutch border.

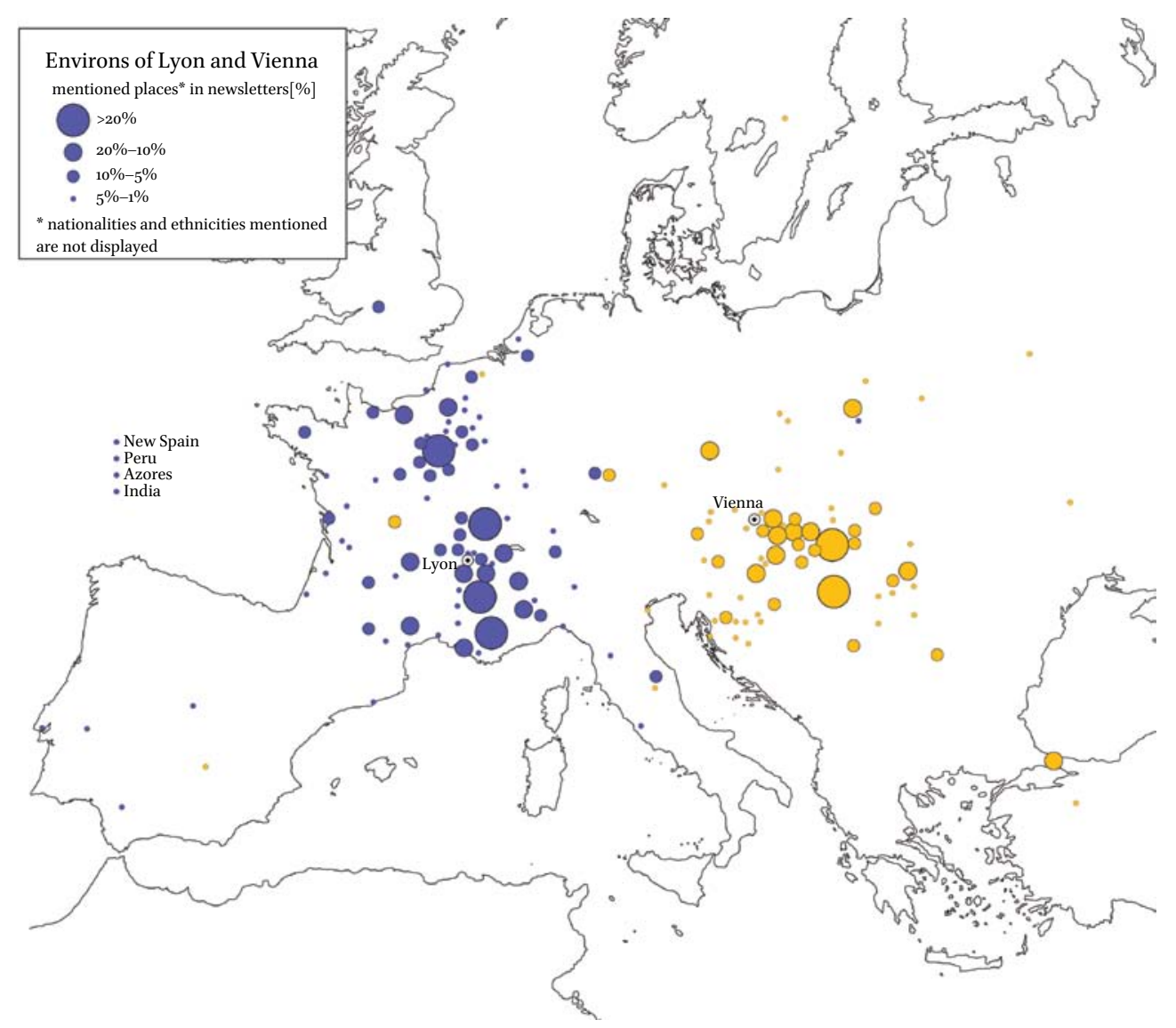

FIGURE 9.5 Catchment area of information for Fuggerzeitungen from Vienna and Lyon 
Furthermore, we find numerous reports from the environs of Lyon (Dauphiné and Provence) as well as news about Savoy and Switzerland, as Duke Karl Emanuel of Savoy was at war with Geneva. At the periphery of the region we find Northern Italy and the southwest of France. These areas are mentioned in the newsletters, but only sporadically. Compared to Lyon the map of the Viennese environs shows us a large number of reports on Hungary. Hungary and Ofen/ Buda are the most frequently-occurring places, followed by Transylvania, Poland, Walachia and Tartary. Reports from the Habsburg territories are comparatively rare. This is mainly due to the large number of Viennese newsletters following the outbreak of the Turkish War. The newsletters from Vienna and Prague deal with a wide variety of topics before the war, but after 1592 the war and related events predominate. During the war these newsletters are often connected to newsletters from border towns, as they were often sent together, or refer to each other.

The Figures 9.6 and 9.7 show the catchment areas of the chief Fuggerzeitungen centres:

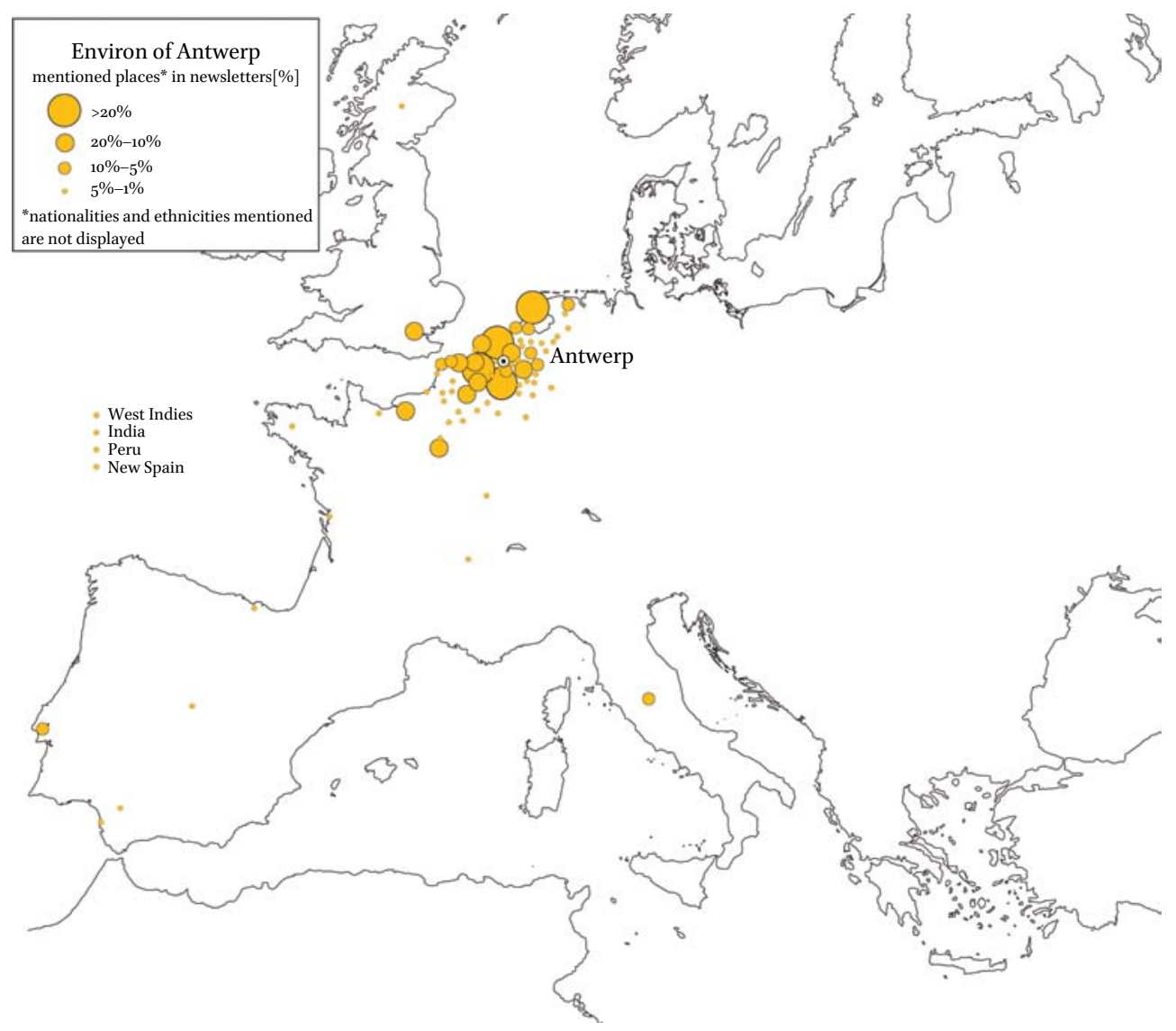

FIGURE 9.6 Catchment area of information for Fuggerzeitungen from Antwerp 


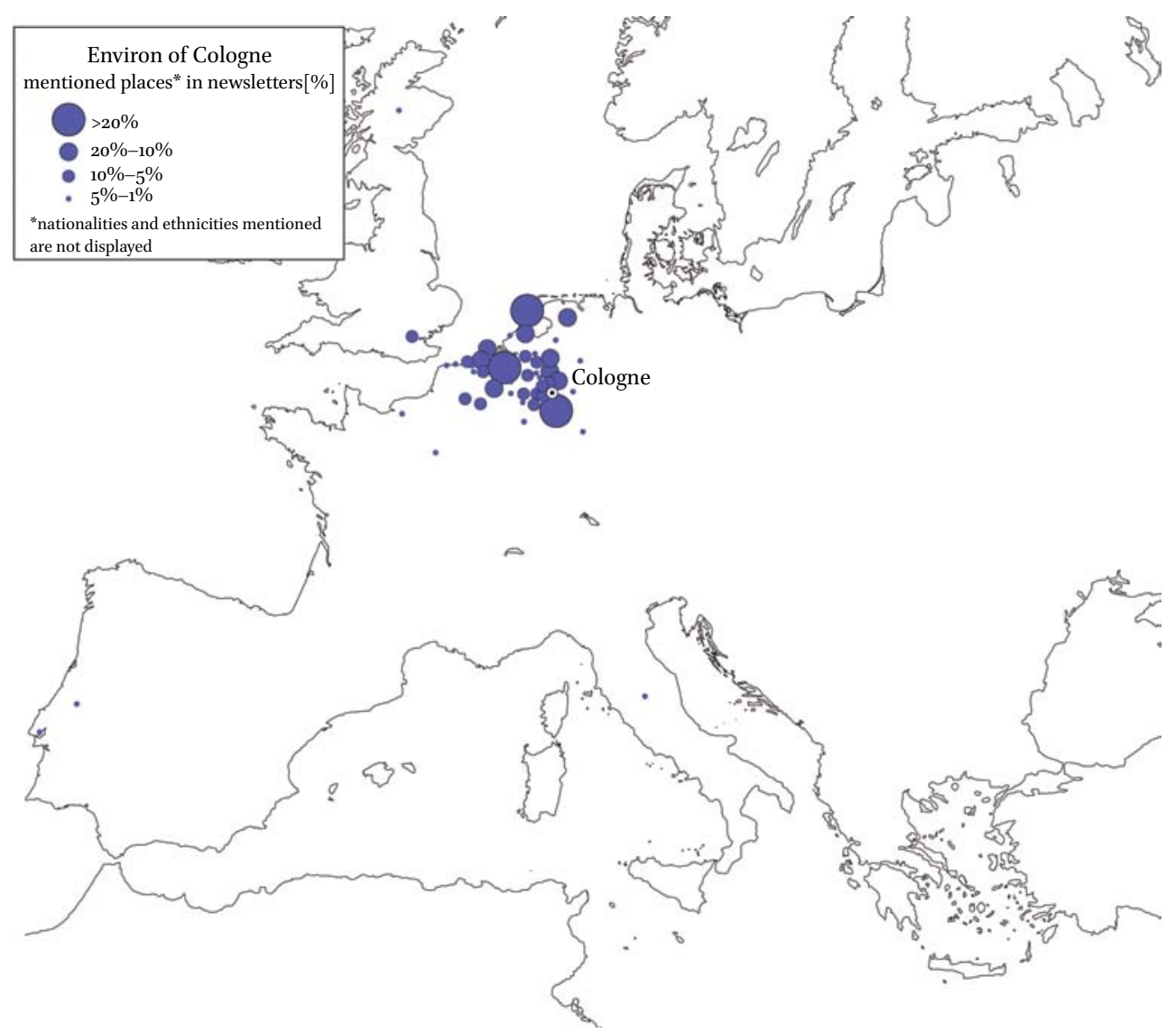

FIGURE 9.7 Catchment area of information for Fuggerzeitungen from Cologne

It is apparent from this map that Antwerp was primarily the collecting point for news from the northern and southern Netherlands, coming in from Brussels, Tournai, Middelburg, Dunkirk, The Hague, and so on. It also processed some news from northern France, with reports from Dieppe, Rouen and Paris. News from England, arriving via London, features regularly in newsletters from Antwerp; news from Spain and the New World, from Lisbon, Sanlúcar de Barameda or Madrid, for instance, is less common. Cologne, connected to Antwerp by a postal route, similarly covered the news from the Netherlands - usually based on newsletters, avvisi and other information channels from Antwerp-and from north-western Germany. News from the southwest, from Speyer or Strasbourg, appears less regularly, and is usually based on news from Antwerp too.

The newsletters from Antwerp and Cologne report mainly on the war-related events in the Netherlands, the Cologne War (1583-8), the Anglo-Spanish wars (especially the Armada) and the wars of religion in France. These accounts focus 
mainly on troop movements, travels of military leaders, sieges and battles. They seldom come directly from the eventual point of dispatch, unless the city was directly involved in a military conflict. In the case of Antwerp, these include the Spanish and the French Furies (1576 and 1584 respectively), the entry into the city and the triumphal procession of the Duke of Alençon (1584), the siege of Antwerp (1585), and the religious conflicts within the city (1580-1).

As seen in figure 9.8, newsletters from Rome focus mainly on the activity of the Roman Curia and events in the Papal States. News from Spain and the Spanish territories in Italy are to be found quite regularly, along with occasional news from Lyon and Tuscany, or about the battles between the Venetians and the Ottomans in the Mediterranean. Reports of events in the city itself occur remarkably often, focusing on the curia, the appointments of cardinals, or detailed reports on conclaves.

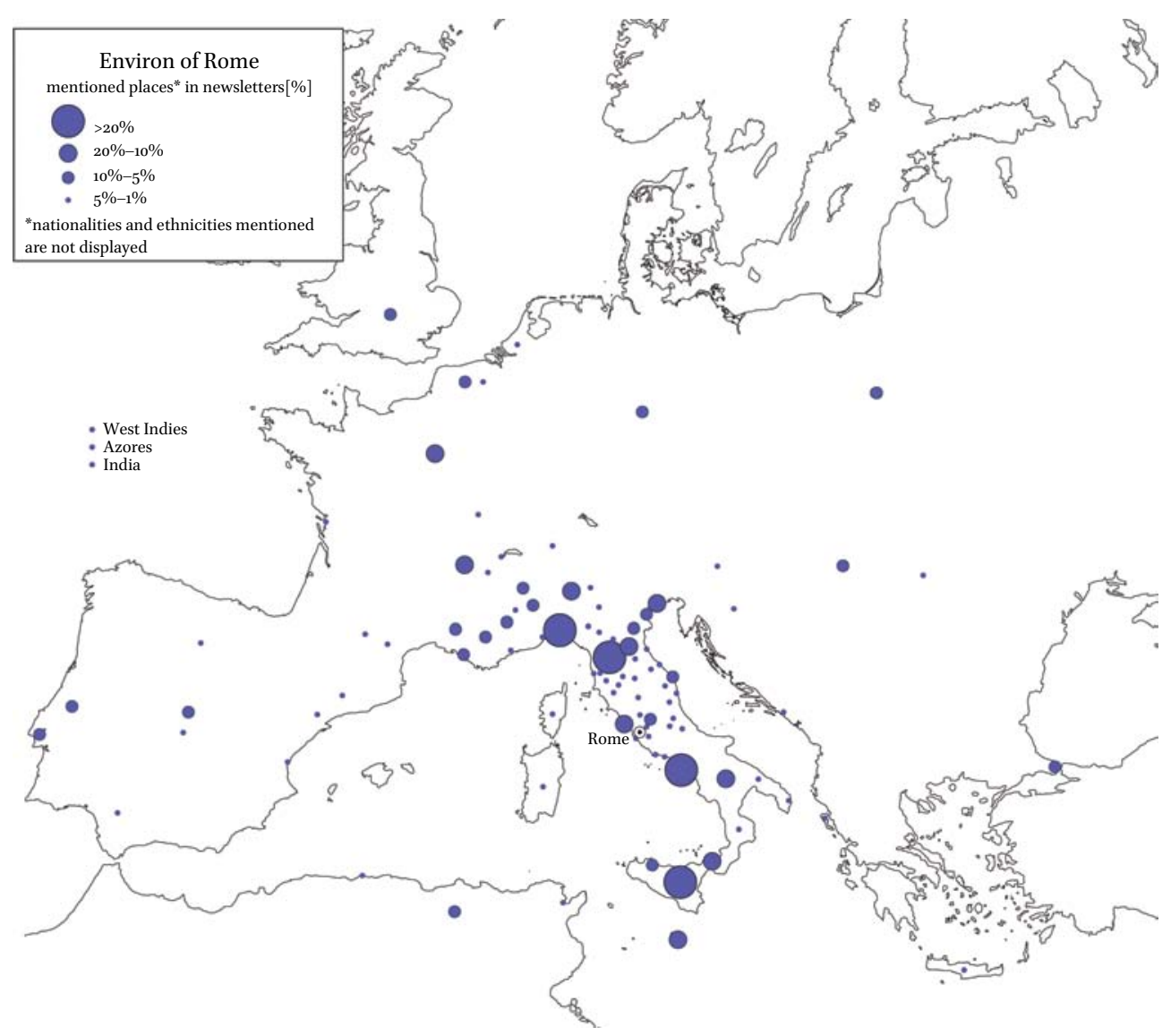

FIGURE 9.8 Catchment area of information for Fuggerzeitungen from Rome 


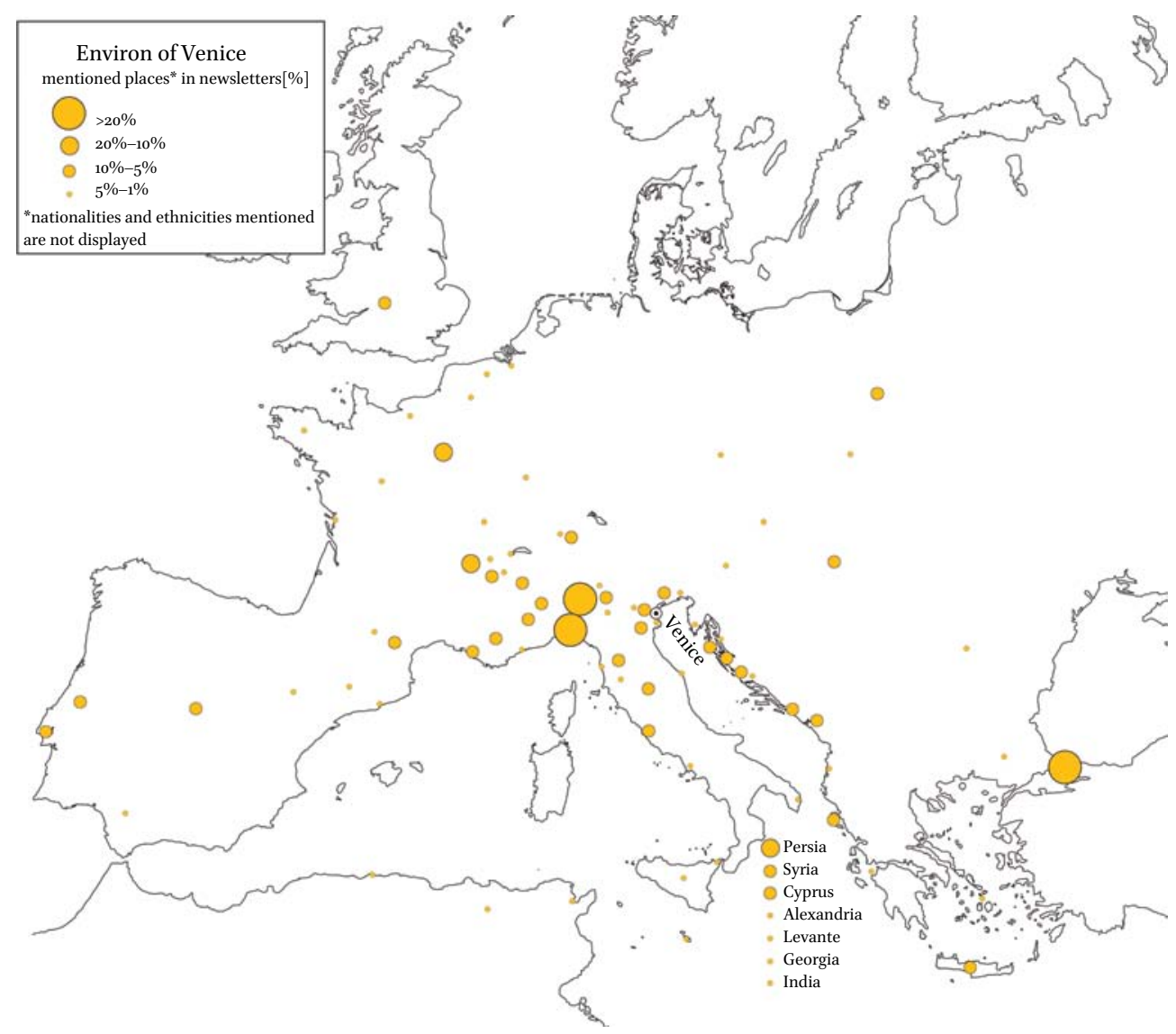

FIGURE 9.9 Catchment area of information for Fuggerzeitungen from Venice

As seen in figure 9.9, the Venetian newsletters focus on Northern Italy, especially Milan, Genoa and Turin, as well as the Adriatic coast, including Ragusa or Corfu, and the Ottoman Empire. There are fewer reports from France, Tuscany, Rome, Northern Africa, Poland or the Imperial Court. Until 1586 Venice played an important role as an entrepôt for news from the Germanspeaking regions, when the network between Prague and Vienna began to improve. Newsletters from Venice are very similar to those from Antwerp or Cologne in the structure of their content. They report little about Venice itself and more about events in the city's surroundings, which extend from Southern France and Northern Italy down to Constantinople and the Levant. They mainly cover acts of war, for example in France, but also events at the Sultan's court. The most frequently reported topics are the war in the Mediterranean and the battles between the Ottomans and the Persians.

Constantinople becomes a more important place of dispatch in the $1580 \mathrm{~s}$ and early 1590s, supplying reports on the Ottoman Empire and Persia. News 
from Georgia, Northern Africa and vassal states like Moldavia, Walachia and the Crimea occurs less frequently.

\section{The Early Modern Information Network}

The basis of the Fuggerzeitungen is the network of postal routes established from the early sixteenth century onwards (see Chapter 2, above). The influence of the postal system on the dispatch of newsletters can be seen in the pattern of distribution from Cologne. The first two volumes of the Fuggerzeitungen contain no newsletters from Cologne at all. Only after the opening of a post office in Cologne in 1577-unfortunately there are no surviving Fuggerzeitungen for that year-the city becomes a major site of information-gathering and distribution point for the Fuggerzeitungen from 1578 onwards. In general the period of the Fuggerzeitungen coincides with the crisis of the Taxis postal service, the predecessor of the later Reichspost. To some extent, however, this crisis precipitated the development of municipal and private courier and postal services, ultimately extending the communication system and making the exchange of information easier and more efficient. ${ }^{25}$

Besides the catchment areas from which they draw information around each major dispatch centre, we can also distinguish communication channels or axes of information. These axes correlate closely with the routes of the postal and courier systems and can be discerned in the structure of the news in the Fuggerzeitungen themselves. Thus an Antwerp newsletter can usually be found on the same physical sheet of paper as one from Cologne, sometimes accompanied by newsletters from Frankfurt or Middelburg as well. ${ }^{26}$ Fuggerzeitungen from Italy usually have reports from Rome and Venice on the same sheet. ${ }^{27}$ The newsletters compiled in this fashion sometimes refer to

25 Behringer, Im Zeichen des Merkur, p. 165.

26 For example, we find the following compilation of related newsletters in önв Cod. 8968, fos. $573 \mathrm{r}-4 \mathrm{~V}$, which were sent together: newsletter from Antwerp dated 15 July 1595; newsletter from The Hague 13 July 1595; newsletter from Amsterdam 15 July 1595; newsletter from Middelburg 13 July 1595 and newsletter from Cologne of 20 July 1595; another example is the bundle of newsletters ön B Cod. 8968 , fos. $577 \mathrm{r}-8 \mathrm{v}$. It contains the following newsletters: Antwerp 8 July 1595, Cologne 13 July 1595 and Frankfurt 16 July 1595. Here we can observe the running times between the information centres. From Antwerp to Cologne usually took five days, from Cologne to Frankfurt three.

27 Newsletters from Rome and Venice are usually together in one bundle. For example öNB Cod. 8969, fo. 823r-v, newsletter from Rome dated from 17 February 1596 and newsletter from Venice 23 February 1596. The running times between Rome and Venice are (except very few exceptions) six days. 
one another; a report from Cologne, for example, might refer to a newsletter from Antwerp written directly above it.

The map in Figure 9.10 outlines the information channels, defined by the connections between related newsletters and by the places mentioned in them. This outline visualises the structure of the information network based on four main axes converging in Augsburg. The places along the axes are interconnected by subsidiary information routes.

We may also note that the communication channels of the Fuggerzeitungen are almost identical with the existing postal routes. As well as showing the principal ways along which information travelled, these also show that information can follow more than one route, as in the case of the false report of the triumph of the Spanish Armada, coming from Spain in the summer of 1588 and making its way across Europe via Rome and Venice to Prague. At the same time

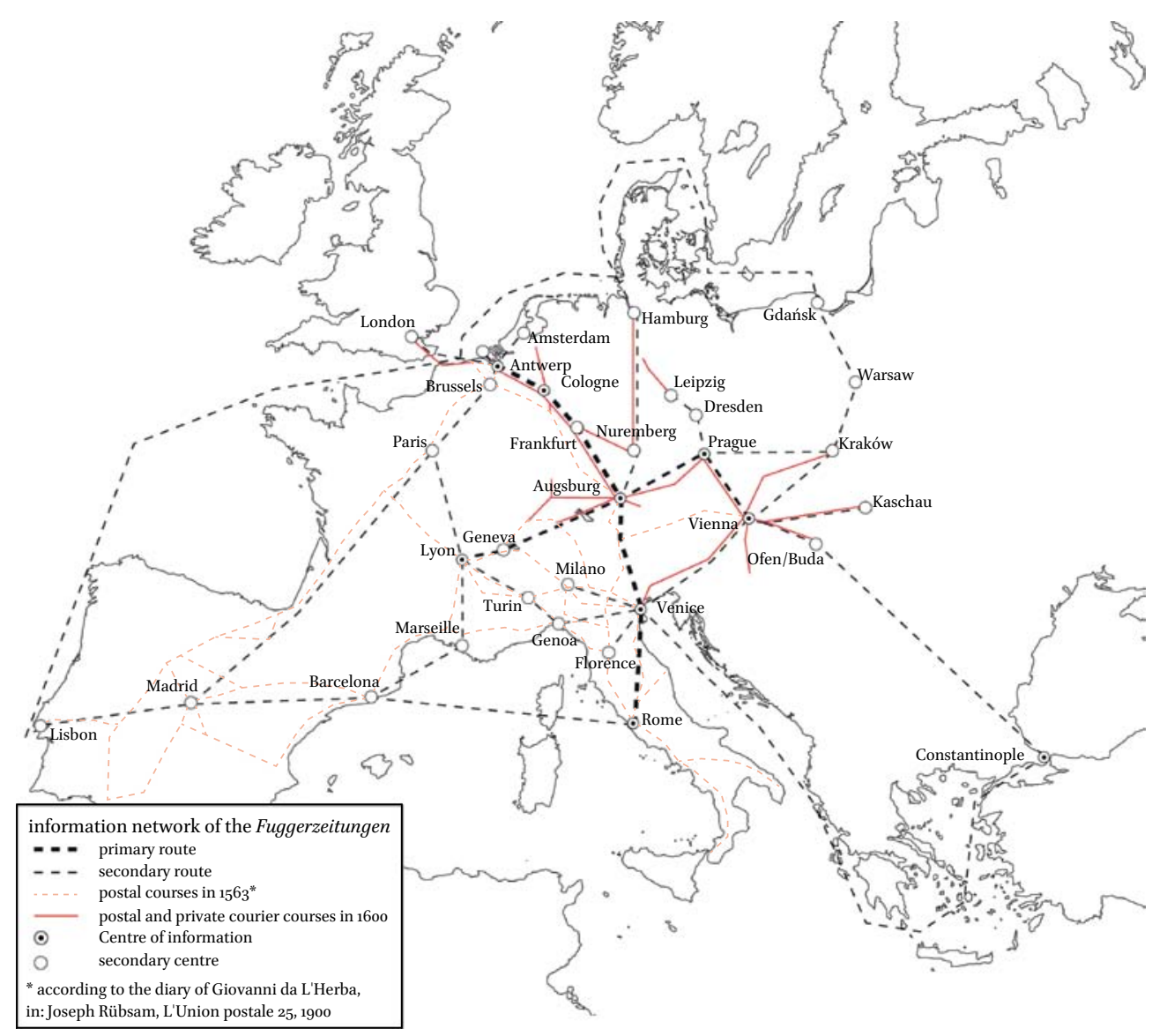

FIGURE 9.10 The information network of the Fuggerzeitungen 
TABLE 9.1 News centres on the four axes of news, as revealed in the Fuggerzeitungen.

\begin{tabular}{|c|c|c|}
\hline Axis & Primary centre & Secondary centre \\
\hline $\begin{array}{l}\text { North-west } \\
\text { (Antwerp-Cologne-Frankfurt-Augsburg) }\end{array}$ & Antwerp, Cologne & $\begin{array}{l}\text { Frankfurt, London, } \\
\text { Middelburg }\end{array}$ \\
\hline South (Rome-Venice-Augsburg) & Rome, Venice & Florence, Milan \\
\hline East (Vienna-Prague-Augsburg) & Vienna, Prague & $\begin{array}{l}\text { Košice, Kraków, } \\
\text { Graz, Leipzig, Buda }\end{array}$ \\
\hline West (Lyon-Augsburg) & Lyon & Geneva, Turin, Paris \\
\hline
\end{tabular}

there were reports from northwestern Europe announcing the Armada's defeat. ${ }^{28}$

Table 9.1 shows the four main axes of news in the Fuggerzeitungen, including primary and secondary centres of information. Certain regions lying outside these four main axes could be connected to the network through a number of routes. For instance, reports from Scandinavia and the north-eastern Baltic area-an important subject in the Fuggerzeitungen especially during the Livonian War (1558-83) — came via Danzig/Gdańsk. From there the letters were passed on south to Hamburg or to Poland (Warschau/Warszawa and Krakau/Kraków) to the south-eastern axis that ended in Prague. From Hamburg there were connections to Antwerp, so sometimes news on the Baltic trade came to Augsburg via the north-western axis.

News from Spain and the New World came to Augsburg in one of three principal ways. ${ }^{29}$ First, along the Atlantic coast, the so-called Biscaya route, ${ }^{30}$

28 Concerning the false reports on the victory of the Spanish Armada see önв Cod. 8961, fo. 549v, resp. ibid. fos. 551r-v (Prague, 30 August 1588), ibid. fos. 575v-6r (Prague, 6 September 1588). All these newsletters report on a victory of the Armada and the beginning Spanish invasion of England. See also Bauer, Zeitungen vor der Zeitung, pp. 318-9.

29 Concerning the postal connections between Spain and the Holy Roman Empire see Arno Strohmeyer, 'Kommunikation und die Formierung internationaler Beziehungen-Das österreichisch-spanische Nachrichtenwesen im Zeitalter Philipps II', Hispania-Austria II-Die Epoche Philipps II. (1556-1598), ed. Friedrich Edelmayer(Vienna, Munich:Oldenbourg Wissenschaftsverlag, 1999), pp. 129-38; on reporting from America, see Renate Pieper, Die Vermittlung einer Neuen Welt-Amerika im Nachrichtennetz des Habsburgischen Imperiums 1493-1598 (Mainz:Vandenhoeck \& Ruprecht, 2000), pp. 272-3, and 'Die Berichterstattung aus der Neuen Welt im ausgehenden 16. Jahrhundert am Beispiel der Fuggerzeitungen', Die Neue Welt im Bewußtsein der Italiener und Deutschen des 16. Jahrhunderts, ed. Adriano Prosperi, Wolfgang Reinhard (Berlin: Duncker \& Humblot, 1993), pp. 157-73. 
whereby newsletters from Spain came in via Antwerp (north-western axis). Alternatively, news from Spain might be passed on via Rome along the southern axis, either through diplomatic relations between the Spanish king and the curia or through Southern Italy, which was under Spanish rule. The third and most common route for Spanish newsletters was via Lyon, the trading centre on the Rhône right along the road from Spain to Southern Germany.

Most French news was filtered through Lyon, which included reports on the court and the French Wars of Religion. Newsletters from Antwerp supply additional information on military events in Northern France. Newsletters from Paris are comparatively rare, usually coming together with newsletters from Lyon. These mainly cover events at the royal court and in the city.

The sequence of reports from Constantinople begins around 1584, with a newsletter from Constantinople arriving roughly every two weeks. This stops altogether with the outbreak of the Turkish War of 1592/93. There are no newsletters from Constantinople between 1593 and 1605 , the final period covered by the Fuggerzeitungen. ${ }^{31}$ News from Constantinople travelled to Augsburg on two routes. It either came by sea and was forwarded via Venice-most likely the correspondents were Venetian and Italian merchants in Constantinople, a theory backed by reports on movements of the Ottoman fleet in the Aegean and occasional quotation of prices. ${ }^{32}$ Alternatively, they came to Vienna by land. The writers of these newsletters are to be found among the entourage of the Imperial Orator at the 'Hohen Pforte', which is why this route ends with the beginning of the Turkish war. In early newsletters from Constantinople (until the mid-1580s) Vienna is often given as the place of dispatch, even though the content is from Constantinople. The content of these letters consists mainly of information on events at the Sultan's court, the arrival of ambassadors, the political attitude towards vassal states, and the election of pashas and viziers, but also on the Ottoman Empire's war against Persia and Georgia.

\section{Spatial Structure of the Reporting}

During the peak years of the Fuggerzeitungen (1580-1600), we can see three levels of reporting, dependent on the origin of the newsletters and resulting from

31 Bauer,Zeitungenvorder Zeitung, p. 67. Exceptions are two newsletters from Constantinople in öNB Cod. 8975 .

32 Reports on Constantinople from Venice contain a wide spectre of topics, for example reports on the court of the Sultan, öNB Cod. 8965 , fos. 707r-8r (Venice, 11 September 1592), plague in the city, ÖN в Cod. 8950, fos. $163^{r}-4 \mathrm{r}$ (Venice, 18 November 1575), or trade and maritime traffic, ÖNB Cod. 8972, fos. 653v-4r (Venice, 5 February 1599). 
the attempt to keep the flow of news continuous and up to date. First we see a near-continuous weekly — and sometimes even more frequent - transmission of newsletters from the four main centres of information: Rome, Venice, Antwerp and Cologne. This basic level of reporting, as we might call it includes the more or less regular incoming newsletters from Lyon, Vienna, Prague, and Constantinople (between 1584 and 1593) as well as Frankfurt (especially before and during the Cologne War between 1584 and 1588) and Middelburg (between 1586 and 1588, focusing on the Spanish Armada, English politics, and the war in the Low Countries). These reports cover the main political and military events in Europe. Newsletters from the four main centres are transmitted regardless of whether there was anything important to report that week.

This 'basic level' is supplemented by reports on major events, which are brought into special focus for a certain period. Examples include the Spanish Armada, the Cologne War, the Long War between the Habsburg Monarchy and the Ottomans (mentioned above) as well as the siege of Geneva, the Strasbourg Bishops' War, the Treaty of Vervins (1598), the pope's claim to the duchy of Ferrara (1598), and the Livonian War (1558-83), but also non-military events such as the royal election in Poland (1587). These events lead to an increase in the number of newsletters dispatched from places related to the events themselves, in addition to the basic reporting from the major centres of information. During the Long War (1593-1606) newsletters from the Hungarian, Transylvanian and Wallachian war zones are transmitted periodically. When Geneva was besieged in 1589 by the Duke of Savoy the city became one of the major centres of reporting, with newsletters arriving almost weekly. ${ }^{33}$ Antwerp and Middelburg doubled their output of newsletters during the Spanish Armada. Once the event was over, the volume of news transmitted from these semi-peripheral (excepting Antwerp), irregular sites of reporting returns to a lower, more normal level.

The third observable dimension of reporting in the Fuggerzeitungen is reports on minor single events, which are of interest for a short period of time. These include battles in the various wars of the period, as well as assassinations, spectacular criminal cases, and natural phenomena. They are of interest for some days and are recorded in a few newsletters, sometimes just the one. ${ }^{34}$ This phenomenon is at the root of the large number of places of dispatch appearing only once or perhaps a couple of times in the corpus of the Fuggerzeitungen.

33 Concerning Geneva see Bauer, Zeitungen vor der Zeitung, pp. 331-42.

34 Examples are the raid on Santo Domingo by Francis Drake in 1586, ÖNB Cod. 8959, fos. 271r-4V (Santo Domingo, 11 January 1586); reports on an earthquake in Vienna in 1590, ÖN B Cod. 8963, fo. 67or-v (Vienna, 24 September 1590) and ibid. fos. 668r-v (Vienna, 23 September 1590), and reports on attempted assassinations on monarchs, for example the assassination attempt on Henri IV of France 1594, Cod. 8967, fos. 776r-v and ibid. fos. 773 r-4r (both dated 14 April 1594). 
The Fuggerzeitungen therefore report constantly on different levels on the prominent political and military events of the time. Over the timespan of the Fuggerzeitungen the four main centres in particular, Rome, Venice, Antwerp and Cologne, develop a specific style of writing, marked by neutrality, objectivity and concision. It is noticeable that this style was imitated at some of the less frequently occurring places of dispatch, such as Lyon, Middelburg or Frankfurt. Newsletters from Vienna and Prague seem less professional, tending to be more straightforwardly pro-Habsburg and written less objectively, and often giving an impression of the political opinion of the writer. This kind of obvious editorial bias is intensified in the occasional newsletters from some of the important points in the network. The style of many of the newsletters coming in from the periphery seems not to have been influenced by the specific style of the professional writers. Small events are described in detail, and subjective statements representing the personal opinion of the writer are common.

The emerging professionalism of the newswriters is apparent not just in linguistic style but in content. Professional newswriters mainly wrote about serious topics, chiefly politics and warfare; by contrast, writers who do not adhere to the specific style of the professional Fuggerzeitungen often reported on more sensational events, such as criminal cases or natural catastrophes, and they often give vivid descriptions of bloody battles, perhaps trying to attract a broader audience. ${ }^{35}$ These newsletters are in fact very similar to the Newe Zeytungen. This specifically German, non-periodical form of printed news describes singular events such as battles, curious happenings, or reports on newly discovered lands. Those Zeytungen focused on reporting the sensational, and were primarily printed for profit. It is reasonable to suppose, on the basis of the style as well as the quality of news, that some of the Fuggerzeitungen might be transcribed Newe Zeytungen. ${ }^{36}$

\section{Summary}

A geographical analysis of the Fuggerzeitungen gives us a good overview of the spatial structures of early modern information society. We can observe a

35 An exception are the newsletters from Venice between 1582 and 1586. During this period we can observe a provincialisation of the newsletters from Venice. The political and military reports, which normally dominated the newsletters, get less important, while gossip reports on murder and crime stories become rampant.

36 Examples are two copies of Newe Zeytungen on two spectacular criminal cases, ö nB Cod. 8959, fos. 247r-8r (Padua, 22 December 1585), and ön B Cod. 8967, fos. 509v-10r (Bavaria, no date, 1594). 
direct relationship between the developing postal routes and the emergence of news networks, apparent from the spatial, and temporal overlap between the newsletters and the postal routes. ${ }^{37}$ This supports the contention that the Fuggerzeitungen were not a private service for the Fugger family and company, written by an employee, but a commercial 'public' medium, which already had established a certain regularity and periodicity.

Secondly, this geographical analysis shows that we have very few newsletters from Augsburg and its immediate neighbourhood. We also find only a few Fuggerzeitungen from the southern parts of the Holy Roman Empire, such as Bavaria, Tyrol, Salzburg, Franconia and Württemberg, and other parts of the Empire are notably underrepresented, for instance northern Germany (the Hanse area, Luneburg, Brandenburg, Mecklenburg, and Pomerania). ${ }^{38}$ The rare newsletters we have from these regions report mainly on curiosities, like the burning of witches, spectacular criminal cases or tournaments. One significant exception is the newsletters from Regensburg, written during the Imperial Diets. In this case we can observe that the writer of those newsletters travelled from Prague to Regensburg - probably accompanying the Imperial Court. For the time of the Imperial Diets in Regensburg we have no newsletters transmitted from Prague, so we can assume Regensburg replaced Prague within the network during this time. ${ }^{39}$ Therefore we can describe the writers-who normally write from Prague-as news correspondents from the Imperial Court who are consequently not bound to one place.

Our overview shows that the Fuggerzeitungen were primarily a transregional informative medium which provided mainly political news from more distant places all over Europe, while news from the Fuggers' more immediate neighbourhoods-mainly the German countries-were covered by other information paths. This is also shown by Oswald Bauer in his study. ${ }^{40} \mathrm{He}$ describes the Fuggerzeitungen as one of three pillars of the informative network of the Fuggers' company. While the handwritten newsletters covered mainly recent events from various European centres, Philipp Eduard and Octavian Secundus Fugger also received more general information on history,

37 Behringer, Im Zeichen des Merkur, pp. 358-65.

38 This as distinct from the Bullingerzeitungen: Barbarics, 'Tinte und Politik', pp. 239-40.

39 For example during the Imperial Diet 1594, see öNB Cod. 8967, fo. $719 \mathrm{v}$ (Regensburg, 20 May 1594), or ibid. fo. 695 ${ }^{\mathrm{r}-\mathrm{v}}$ (Regensburg, 5 June 1594); altogether between 20 May and 25 August 1594 we find 22 newsletters and related texts sent from Regensburg, but no single one from Prague; the transmission from Prague ends on 6 May and again sets in on 4 September. The newsletters from Regensburg stand, as those from Prague, in context to newsletters from Vienna and places from the Hungarian border. 
geography and politics from books bought for their library. Further commercial communication happened through personal contact with the company's employees, so newsletters and business correspondence complement each other. ${ }^{41}$

It is striking that events at the places of dispatch do not always play a role in the newsletters. Our focus on the places where news was actually collected, as well as on the content of the information dispatched shows that the main aim was not to inform readers about what was going on at the 'publishing places'. Commercial and residential cities become important as marketplaces of information. Of course there is also news from the places of dispatch, but in general most of the information written down comes from a broader catchment area, as defined above. At the same time it is crucial to note that the importance of the major centres for the collection and dispatch of news fluctuates. Cologne, for example, functions as a relay point for news from the Netherlands and the Lower Rhine around 1580; by 1600 the Cologne newsletters have dwindled significantly. Whether this was due to the writer, to the nature of events, or to competition from Antwerp, we cannot tell.

41 Bauer, Zeitungen vor der Zeitung, pp. 130-2. 